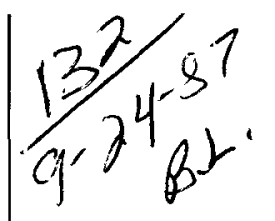

ORNL/TM-10467

\section{OAK RIDGE NATIONAL LABORATORY}

MARTIN MARIETRA

\section{Review of Diffusion Barrier Technology for Application in SP-100 Fuel Pins}

\author{
M. A. Schmidt \\ M. J. Kania
}

OPERATED BY

MARTIN MARIETTA ENERGY SYSTEMS, INC

FOR THE UNITED STATES

DEPARTMENT OF ENERGY 


\section{DISCLAIMER}

This report was prepared as an account of work sponsored by an agency of the United States Government. Neither the United States Government nor any agency Thereof, nor any of their employees, makes any warranty, express or implied, or assumes any legal liability or responsibility for the accuracy, completeness, or usefulness of any information, apparatus, product, or process disclosed, or represents that its use would not infringe privately owned rights. Reference herein to any specific commercial product, process, or service by trade name, trademark, manufacturer, or otherwise does not necessarily constitute or imply its endorsement, recommendation, or favoring by the United States Government or any agency thereof. The views and opinions of authors expressed herein do not necessarily state or reflect those of the United States Government or any agency thereof. 


\section{DISCLAIMER}

Portions of this document may be illegible in electronic image products. Images are produced from the best available original document. 
Printed in the United States of America. Available from National Technical Information Service

U.S. Department of Commerce

5285 Port Royal Road, Springfield, Virginia 22161

NTIS price codes-Printed Copy: A02 Microfiche A01

This report was prepared as an account of work sponsored by an agency of the United States Government. Neither the United States Government nor any agency thereof, nor any of their employees, makes any warranty, express or implied, or assumes any legal liability or responsibility for the accuracy, completeness, or usefulness of any information, apparatus, product, or process disclosed, or represents that its use would not infringe privately owned rights. Reference herein to any specific commercial product, process, or service by trade name, trademark, manufacturer, or otherwise, does not necessarily constitute or imply its endorsement, recommendation, or favoring by the United States Government or any agency thereof. The views and opinions of authors expressed herein do not necessarily state or reflect those of the United States Government or any agency thereof. 


\section{DISCLAIMER}

This report was prepared as an account of work sponsored by an agency of the United States Government. Neither the United States Government nor any agency thereof, nor any of their employees, makes any warranty, express or implied, or assumes any legal liability or responsibility for the accuracy, completeness, or usefulness of any information, apparatus, product, or process disclosed, or represents that its use would not infringe privately owned rights. Reference herein to any specific commercial product, process, or service by trade name, trademark, manufacturer, or otherwise does not necessarily constitute or imply its endorsement, recommendation, or favoring by the United States Government or any agency thereof. The views and opinions of authors expressed herein do not necessarily state or reflect those of the United States Government or any agency thereof.
ORNL/TM- 10467

Distribution Category UC-25

\section{REVIEW OF DIFFUSION BARRIER TECHNOLOGY FOR APPLICATION IN SP-100 FUEL PINS}

M. A. Schmidt and M. J. Kania

Date Published: August 1987

NOTICE: This document contains information of a preliminary nature. It is subject to revision or correction and therefore does not represent a final report.

Prepared by the

OAK RIDGE NATIONAL LABORATORY

Oak Ridge, Tennessee 37831

operated by

MARTIN MARIETTA ENERGY SYSTEMS, INC.

for the

U.S. DEPARTMENT OF ENERGY under Contract DE-AC05-840R21400

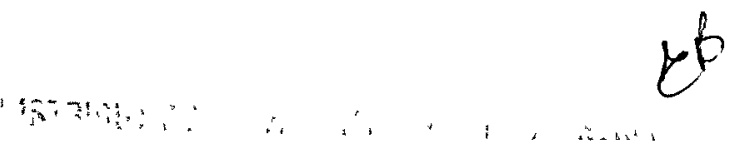


PAGE BLANK

ii 
CONTENTS

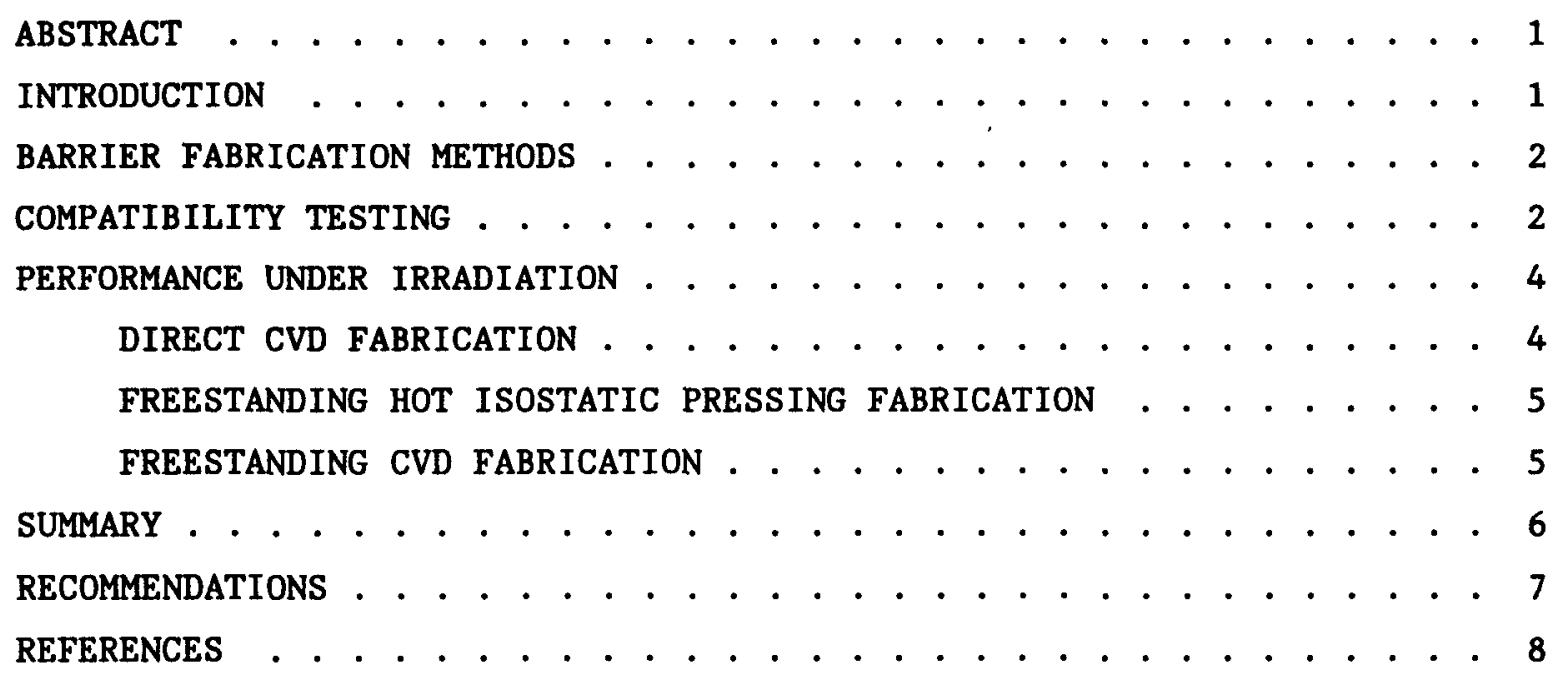




\section{REVIEW OF DIFFUSION BARRIER TECHNOLOGY FOR APPLICATION IN SP-100 FUEL PINS ${ }^{*}$}

M. A. Schmidt and M. J. Kania

ABSTRACT

The fuel pin design for the SP-100 reactor uses uranium nitride fuel contained in a niobium alloy $(\mathrm{Nb}-1 \mathrm{Zr})$ cladding. Chemical reactions occur between the fuel and the cladding at the planned operating temperatures of 1350 to $1500 \mathrm{~K}$, so a diffusion barrier is required to prevent degradation. The technology associated with diffusion barriers in similar fuel pins is reviewed to identify fabrication techniques and to summarize previous results of chemical compatibility and irradiation tests. Four fabrication techniques were identified. In previous tests, diffusion barriers have performed successfully for up to $12,000 \mathrm{~h}$ at cladding temperatures near $1300 \mathrm{~K}$. A significant challenge remains to develop and qualify a diffusion barrier for the SP-100 mission application, which has a lifetime greater than $60,000 \mathrm{~h}$.

\section{INTRODUCTION}

The SP-100 reactor is compact, lithium-cooled, and designed to operate in a space environment. The fuel element consists of sintered uranium nitride (UN) pellets, a 0.13-mm-thick (0.005-in.) diffusion barrier, and a niobium alloy ( $\mathrm{Nb}-1 \mathrm{Zr})$ cladding. At fuel operating temperatures of 1350 to $1500 \mathrm{~K}$, chemical reactions could occur between the UN and the $\mathrm{Nb}-1 \mathrm{Zr}$ by the following mechanisms: (1) reduction of the $\mathrm{UN}$ by $\mathrm{Nb}-1 \mathrm{Zr}$, (2) reaction of the $\mathrm{Nb}-1 \mathrm{Zr}$ with any free uranium in the fue 1 , and (3) reaction between $\mathrm{Nb}-1 \mathrm{Zr}$ and nitrogen released from the fuel. ${ }^{1}$ A diffusion barrier compatible with both the fuel and cladding is necessary to physically separate the two and prevent the first two types of interactions.

\footnotetext{
*This research was sponsored by the Division of Defense Energy Projects, U.S. Department of Energy, under Contract DE-AC05-840R21400 with Martin Marietta Energy Systems, Inc.
} 
Previous space reactor programs developed fuel pin designs similar to that for SP-100, and the diffusion barrier technology developed in those programs can guide barrier development for the SP-100 project.

Fabrication techniques, compatibility studies, and irradiation effects are reviewed to assess the performance of diffusion barriers in applications similar to SP-100.

\section{BARRIER FABRICATION METHODS}

Earlier work on 1ithium-cooled reactor concepts, including Pratt and Whitney's SNAP-50 program ${ }^{2}$ and NASA's work on an advanced space power nuclear reactor concept, ${ }^{3}$ utilized fuel pin designs similar to those for SP-100. In the SNAP-50 program, the UN fuel pellets were contained in a tungsten-lined $\mathrm{Nb}-1 \mathrm{Zr}$ or $\mathrm{PWC}-11(\mathrm{Nb}-1 \mathrm{Zr}-0.1 \mathrm{C})$ cladding and operated at a coolant outlet temperature of about $1100 \mathrm{~K}$. The advanced space power nuclear reactor concept employed UN pellets in a tungsten-lined T-111 cladding (Ta-8W-2Hf) and operated at a coolant outlet temperature of about $1225 \mathrm{~K}$.

Diffusion barriers used in the SP-100 program have been freestanding tubes fabricated by chemical vapor deposition (CVD)." Other methods of fabricating diffusion barriers were investigated by NASA and NASA contractors. Fabrication methods investigated to produce tungsten diffusion barriers include

(1) direct CVD of tungsten on the inner diameter of cladding,

(2) hot isostatic pressing (HIP) of multiple wraps of wrought tungsten foil into a freestanding tube,

(3) thermal expansion pressing of multiple wraps of wrought tungsten foil against the inner diameter of cladding, 5 and

(4) CVD of tungsten on the outer diameter of a mandrel followed by removal of the mandre1 to form a freestanding tube.

\section{COMPATIBILITY TESTING}

Diffusion couples were investigated for the SNAP-50 program to study the $\mathrm{UN} / \mathrm{Nb}-1 \mathrm{Zr}$ reaction and to identify potential diffusion barrier materials. ${ }^{2}$ Couples of $\mathrm{UN}$ and $\mathrm{Nb}-1 \mathrm{Zr}$ evaluated at 1477 and $1589 \mathrm{~K}$ 
determined the extent of the fuel-cladding reaction. After $5000 \mathrm{~h}$ at $1477 \mathrm{~K}$, the reaction layer composed of $\mathrm{Nb}_{2} \mathrm{~N}$ and $\mathrm{NbU}$ alloy was $0.36 \mathrm{~mm}$ ( 0.014 in.) thick.

Tungsten, tungsten-rhenium alloy ( $W-26 R e)$, tantalum, and molybdenum wrought materials were tested as potential barriers in additional diffusion couples. Tantalum reacted with UN to depths of 0.13 to $0.18 \mathrm{~mm}$ ( 0.005 to $0.007 \mathrm{in.})$ after 100 to $500 \mathrm{~h}$ at $1477 \mathrm{~K}$. Molybdenum reacted with UN to depths of 0.003 to $0.41 \mathrm{~mm}(0.0001$ to $0.016 \mathrm{in.})$ after 1000 to $6000 \mathrm{~h}$ at $1366 \mathrm{~K}$. Tantalum and molybdenum were too reactive to be effective diffusion barriers. No reaction was observed between UN and $\mathrm{W}-26 \mathrm{Re}$ after $5000 \mathrm{~h}$ at $1477 \mathrm{~K}$. Tungsten was also very stable in a diffusion couple of $U N / W / N b-1 Z$ r with no reaction observed after $3500 \mathrm{~h}$ at $1477 \mathrm{~K}$. With increased exposure times of 5000 and $5863 \mathrm{~h}$ at $1477 \mathrm{~K}$, uranium penetration into the $\mathrm{Nb}-1 \mathrm{Zr}$ was observed to depths of 0.08 and $0.13 \mathrm{~mm}(0.003$ and $0.005 \mathrm{in.})$, and a $\mathrm{NbW}$ phase was present in the tungsten barrier. At higher temperatures, no reaction was observed after $100 \mathrm{~h}$ at $1589 \mathrm{~K}$, but a $\mathrm{Nb}_{2} \mathrm{~N}$ precipitate was observed in the $\mathrm{Nb}-1 \mathrm{Zr}$ after $100 \mathrm{~h}$ at $1700 \mathrm{~K}$. The UN decomposed after $100 \mathrm{~h}$ at $1811 \mathrm{~K}$.

The SNAP-50 program also tested simulated fuel pins of UN/W/Nb-1Zr in liquid lithium. ${ }^{2}$ The tungsten barrier was deposited directly on the inner diameter of the cladding by the CVD process. The simulated fuel pins were tested at $1477 \mathrm{~K}$ for times of 1000 to $11,000 \mathrm{~h}$. A diffusion layer of niobium in the tungsten barrier was observed with depths varying from 0.01 to $0.08 \mathrm{~mm}$ ( 0.0005 to $0.003 \mathrm{in.})$. $\mathrm{A} \mathrm{Nb}_{2} \mathrm{~N}$ precipitate was dispersed throughout the $\mathrm{Nb}-1 \mathrm{Zr}$ cladding.

Compatibility of a UN/W/T-111 fuel-pin system at temperatures between 2075 and $2975 \mathrm{~K}$ was investigated using a freestanding HIPed tungsten barrier tube. 6 Posttest evaluation revealed that for short time periods (10 min) at $2775 \mathrm{~K}$ and below, no evidence of fuel-barrier-cladding interaction was visible with the exception of some noticeable bonding between fuel and barrier. At temperatures above $2775 \mathrm{~K}$, the tungsten diffusion barrier did not prevent reaction between fuel and cladding, and rapid decomposition of the fuel occurred. The resulting liquid uranium wet the barrier and penetrated all cracks, overlaps, and the barriercladding interface. It was concluded that at temperatures above $2775 \mathrm{~K}$ fuel decomposition occurs producing liquid uranium, which wets capsule 
interior surfaces and ultimately reaches the cladding surface. The degree of barrier and cladding attack depended on the extent of fuel decomposition.

\section{PERFORMANCE UNDER IRRADIATION}

A significant quantity of data exists on diffusion barrier performance determined from postirradiation examination of in-reactor tests. Barriers produced by all of the fabrication methods listed previously (except for the differential thermal expansion method) have been evaluated after irradiation.

\section{DIRECT CVD FABRICATION}

Irradiation tests were conducted in support of the fuel-pin design utilizing CVD of tungsten directly onto the cladding. Forty-one fuel pins composed of UN/W/PWC-11 were irradiated in the Materials Test Reactor (MTR) at cladding temperatures of about 1110 to $1480 \mathrm{~K}$, burnups of 0.58 to 4.58 at. \% U, and times of 2635 to nearly 12,000 h (ref. 7). No defective fuel pins were detected during postirradiation examination, but examination of the 0.13-mm-thick (0.005-in.) CVD tungsten barrier revealed numerous cracks. A reaction zone between the tungsten barrier and PWC-11 cladding was noted in most fuel pins consisting of a NbW interdiffusion region and a UNb intermetallic region. This reaction zone was about $0.02 \mathrm{~mm}$ ( $0.001 \mathrm{in.})$ thick in the high-temperature $(1473 \mathrm{~K})$ pins and decreased in thickness with decreasing fuel-pin cladding temperature. Cracks in the barrier did not appear to have accelerated the reaction. It was postulated that uranium migrated along columnar grain boundaries of the CVD tungsten to the PWC-11 cladding.

Two fuel pins consisting of UN/W/T-111 were irradiated in the Oak Ridge Research Reactor (ORR) at cladding temperatures of about $1673 \mathrm{~K}$ for $5800 \mathrm{~h}$ to burnups of 1.75 at. \% U (ref. 8). The CVD tungsten barrier for these pins was $0.08 \mathrm{~mm}$ ( $0.003 \mathrm{in.})$ thick. The performance of these fuel pins was quite different from that discussed above; one of them failed by intergranular cracking of the T-111 cladding, and the other was near failure because of cracks and cavities in the T-111. Examination revealed numerous intergranular cracks and cavities in the tungsten barrier and extrusion of the UN fuel into cracks in the barrier. In some 
instances the UN had bonded to and penetrated the tungsten barrier up to about $0.015 \mathrm{~mm}(0.0006 \mathrm{in}$ ) . The poor performance of the T-111 cladding and the CVD tungsten barrier in this experiment was attributed to the linking together of grain boundary gas bubbles under tensile stress. ${ }^{1}, 10$ FREESTANDING HOT ISOSTATIC PRESSING FABRICATION

Six fuel pins utilizing a UN/W/T-111 fuel-barrier-cladding design were irradiated in the $O R R$ at about $1265 \mathrm{~K}$ cladding temperature for approximately $10,000 \mathrm{~h}$ to a burnup of about 3 at. \% U (ref. 11). The barrier material in this pin design was a $0.08-\mathrm{mm}-$ thick (0.003-in.) freestanding wrought tube fabricated by hot isostatic pressing. The postirradiation examination revealed major cladding cracks in two fuel pins resulting from hydrogen embrittlement of the $\mathrm{T}-111$. Al1 the barriers had some cracks, but no fuel-barrier or barrier-cladding reactions were evident. It was concluded that even though cracks would occur in the liner during irradiation, they should not cause compatibility problems provided UN did not contact T-111 cladding.

FREESTANDING CVD FABRICATION

The first series of SP-100 irradiation experiments (SP-1, SP-2, and the planned SP-3) have as part of their test matrix a $\mathrm{UN} / \mathrm{W} / \mathrm{Nb}-1 \mathrm{Zr}$ or UN/W/PWC-11 fue1-pin design in which the barriers are $0.13-\mathrm{mm}$-thick (0.005-in.) freestanding tungsten tubes fabricated by the CVD process. The SP-1 and SP-2 irradiation experiments are being conducted in the EBR-II reactor at cladding temperatures of 1300 and $1500 \mathrm{~K}$ to fuel burnups of 0.8 to 3.8 at. $\% \mathrm{U}$.

Postirradiation examinations performed on the first phase of the SP-1 test indicated that no fuel-pin failures occurred; however, interactions between the UN fuel and the tungsten barrier and between the barrier and the $\mathrm{Nb}-1 \mathrm{Zr}$ cladding did occur. ${ }^{4,12}$ The barriers showed evidence of intergranular cracking of the CVD tungsten similar to that reported in ref. 8. A NbW solid solution was identified by microprobe analysis at the barrier-cladding interface. Microprobe analysis also indicated the presence of free uranium at the fuel-barrier interface, probably due to 
the high operating temperature (1960 K surface) of the hypostoichiometric UN fuel. Molybdenum may have accelerated the UN dissociation. It was present as an impurity both in the tungsten barrier and on the surface of the UN fuel pellet. Ruthenium, a metallic fission product, was also found deposited between the barrier and the cladding material. No interactions were observed between the $\mathrm{UN}$ fuel and the $\mathrm{Nb}-1 \mathrm{Zr}$ cladding; the tungsten tube functioned as a suitable diffusion barrier under the exposure conditions.

\section{SUMMARY}

Compatibility tests evaluated $\mathrm{Ta}, \mathrm{Mb}, \mathrm{W}$, and WRe alloy (W-26Re) as potential diffusion barriers for $\mathrm{UN}$ and $\mathrm{Nb}-1 \mathrm{Zr}$. Tantalum and molybdenum were incompatible with UN at temperatures of 1477 and $1366 \mathrm{~K}$, respectively. The WRe alloy did not react with UN after $5000 \mathrm{~h}$ at $1477 \mathrm{~K}$. Tungsten was quite stable, but formed a $0.13-\mathrm{mm}(0.005-\mathrm{in}$.) reaction layer with $\mathrm{Nb}-1 \mathrm{Zr}$ after $5863 \mathrm{~h}$ at $1477 \mathrm{~K}$ in a diffusion couple. This reaction layer was only $0.08 \mathrm{~mm}$ ( 0.003 in.) thick in a simulated fuel pin tested in liquid lithium after $11,000 \mathrm{~h}$ at $1477 \mathrm{~K}$.

Irradiation experience with diffusion barriers is summarized in Table 1. Fuel pins have been tested with tungsten as a diffusion barrier between UN fuel and three different cladding naterials: $\mathrm{Nb}-1 \mathrm{Zr}, \mathrm{PWC}-11$, and T-111. Tungsten barriers have consistently cracked during irradiation, regardless of the fabrication method or the cladding type. Barrier-cladding interactions were observed for the niobium alloy claddings, $\mathrm{Nb}-1 \mathrm{Zr}$ and $\mathrm{PWC}-11$, but were not present with the $\mathrm{T}-111$ cladding.

Table 1. Summary of irradiation experience with tungsten barriers in UN fuel pins

\begin{tabular}{|c|c|c|c|c|c|c|c|c|c|}
\hline \multirow[b]{2}{*}{ Clad } & \multirow[b]{2}{*}{ Barrier type } & \multirow{2}{*}{$\begin{array}{l}\text { Cladding } \\
\text { temperature } \\
\text { (K) }\end{array}$} & \multirow{2}{*}{$\begin{array}{r}\text { Time } \\
\text { (h) }\end{array}$} & \multirow{2}{*}{$\underset{\text { (at. } \mathcal{X} U)}{\text { Burnup }}$} & \multirow{2}{*}{$\begin{array}{l}\text { Cladding } \\
\text { failure }\end{array}$} & \multicolumn{3}{|c|}{ Observed interactionse } & \multirow[b]{2}{*}{ Reference } \\
\hline & & & & & & $\begin{array}{l}\text { Barrier- } \\
\text { cladding }\end{array}$ & $\begin{array}{l}\text { Barrier- } \\
\text { fuel }\end{array}$ & $\begin{array}{c}\text { Fuel- } \\
\text { cladding }\end{array}$ & \\
\hline PWC-11 & Direct CVD $W$ & $1,100-1,480$ & $2,635-12,000$ & $0.58-4.58$ & 0 of 41 & yes &.- & yes & 7 \\
\hline $\mathrm{T}-111$ & Direct CVD W & 1,673 & 5,800 & 1.75 & 1 of 2 & no & yes & no & 8 \\
\hline$T-111$ & HIP W tube & 1,265 & 10,000 & 2.8 & 2 of 6 & no & no & no & 11 \\
\hline $\mathrm{Nb}-12 \mathrm{r}$ & CVD $W$ tube & $1,500-1,600$ & 2,400 & 0.8 & 0 of 2 & yes & yes & no & 4 \\
\hline
\end{tabular}

${ }^{a}$ Cracked barriers were found in all experiments. 
Interactions between the tungsten barrier and the UN fuel were observed at cladding temperatures above $1500 \mathrm{~K}$ but not at $1265 \mathrm{~K}$.

Despite the postirradiation condition of the barriers, the performance of the fuel pins clad with niobium alloys was good. No failures of either $\mathrm{Nb}-1 \mathrm{Zr}$ or PWC-11 cladding were observed, although some fuel-cladding interactions were identified in ref. 7 . The performance of the diffusion barriers was therefore adequate for the conditions. Failure of the T-111 cladding was observed in refs. 8 and 11 , but no fuel-cladding interactions were present. The diffusion barrier served its purpose - to prevent direct chemical interaction between UN and T-111 - but did not prevent failure of the T-111 cladding.

The performance data available on tungsten diffusion barriers fabricated by several methods can be used to estimate their value for current SP-100 reactor operating conditions. The data clearly demonstrate an operating lifetime of 10,000 to $12,000 \mathrm{~h}$ for a fuel-barrier-cladding design of UN/W/PWC-11, fuel operating temperature of 1400 to $1500 \mathrm{~K}$, cladding temperature of about $1300 \mathrm{~K}$, and peak burnup in excess of 4 at. \% U. Longer lifetimes may be likely, but the experimental data base only extends to $12,000 \mathrm{~h}$. The UN fuel was fabricated by a procedure different from the present SP-100 reference procedure, so revalidation of the fuel system performance is required.

The barrier fabrication methods discussed in this assessment were direct CVD of tungsten on the inner surface of cladding and HIPing of thin tungsten foils into freestanding tubes. For the HIPing method, a UN/W/T-111 fuel-pin design was used. In both methods, the barrier material was 0.13 -mm-thick (0.005-in.) unalloyed tungsten. It should be noted that only small-scale pins 150 to $300 \mathrm{~mm}$ long (6 to $12 \mathrm{in}$.) were tested.

\section{RECOMMENDATIONS}

A significant challenge remains to develop and qualify a barrier material and select a fabrication method adequate for the SP-100 mission application. The barriers employed in past programs were designed for 
systems operating at lower fuel and cladding temperatures and for reduced system 1ifetimes. Further, the UN fuel was fabricated by a method different from that used for SP-100.

Developing an effective diffusion barrier technology will require characterizing a number of candidate fabrication methods through activities closely integrated with the fuel development efforts and the fuel system irradiation experiments. Currently, only freestanding CVD tubes have been evaluated. Barriers fabricated by direct CVD inside the cladding or by HIPing of wrought foils are also of interest. Materials besides tungsten, such as Re or WRe alloys, should also be evaluated. Fuel-pin performance could be improved by removing the barrier-cladding gap during fabrication, either by direct CVD onto the cladding, HIPing of the cladding onto the barrier, drawing the cladding onto the barrier, or by some other method producing a bonded (duplex) barrier-cladding tube. The barrier fabrication method selected will require scale-up to produce full-size fuel pins.

\section{REFERENCES}

1. C. M. Cox, D. S. Dutt, and R. A. Karnesky, "Fuel Systems for Compact Fast Space Reactors," pp. 301-06 in Space Nuclear Power Systems 1984, M. S. E1-Genk and M. D. Hoover, eds., Orbit Book Co., Malabar, Fla. (1985).

2. M. A. DeCresente, M. S. Freed, and S. D. Caplow, Uranium Nitride Fuel Development SNAP-50, PWAC-488, Pratt \& Whitney Aircraft, Middletown, Conn., 1965.

3. R. E. Gluyas and G. K. Watson, Materials Technology for an Advanced Space Power Nuclear Reactor Concept - Program Summary, NASA TN D-7909, Lewis Research Center, Cleveland, Ohio, 1975.

4. R. B. Matthews, K. M. Chidester, C. W. Hoth, R. E. Mason, and R. L. Petty, Fabrication and Testing of Uranium Nitride Fuel for Space Power Reactors, LA-10636, Los Alamos National Laboratory, Los Alamos, N.M. , 1986. 
5. G. K. Watson, J. D. Whittenberger, and W. F. Mattson, Therma1-Expansion Method for Lining Tantalum Alloy Tubing with Tungsten, NASA TN D-7426, Lewis Research Center, Cleveland, Ohio, 1973.

6. K. J. Bowles, Off-Design Temperature Effects on Nuclear Fuel Pins for an Advanced Space Power Reactor Concept, NASA TM X-2981, Lewis Research Center, Cleveland, Ohio, 1974.

7. S. C. Weaver, J. L. Scott, R. L. Senn, and B. H. Montgomery, Effects of Irradiation on Uranium Nitride Under Space-Reactor Conditions, ORNL-4461, 1969.

8. D. R. Cuneo, E. L. Long, Jr., A. Jostsons, and T. N. Washburn, Examination of Irradiated Uranium Nitride Fuel Clad with Tungsten-Rhenium or T-111 A11oy, ORNL/TM-3895, 1972.

9. K. Farrell, J. T. Houston, and A. C. Schaffhauser, "The Growth of Grain Boundary Gas Bubbles in Chemically Vapor Deposited Tungsten," pp. 363-90 in Proceedings of the Conference on Chemical Vapor Deposition of Refractory Metals, Alloys, and Compounds, Gatlinburg, Tenn., September 12-14, 1967, A. C. Schaffhauser, ed., American Nuclear Society, Hinsdale, I11. (1967).

10. J. 0. Stiegler, K. Farre11, B. T. M. Loh, and H. E. McCoy, "Nature of Creep Cavities in Tungsten," ASM (American Society for Metals) Trans. Quart. 60(3), 494-503 (1967).

11. K. J. Bowles and R. E. Gluyas, Evaluation of Refractory Meta1-Clad Uranium Nitride and Uranium Dioxide Fuel Pins After Irradiation for Times up to 10,450 Hours at $990^{\circ} \mathrm{C}$, NASA TN D-7891, Lewis Research Center, Cleveland, Ohio, 1975.

12. R. A. Karnesky and R. E. Mason, "Postirradiation Examination Results from SP-1," pp. RF-3.1-3.6 in Trans. 3rd Symposium on Space Nuclear Power Systems, CONF-860102-Summs., University of New Mexico, Albuquerque, 1986. 
ORNL/TM- 10467

Distribution Category UC-25

\section{INTERNAL DISTRIBUTION}

1-2. Central Research Library

3. Document Reference Section

4-5. Laboratory Records Department

6. Laboratory Records, ORNL RC

7. ORNL Patent Section

8. D. E. Bartine

9. T. M. Besmann

10. R. H. Cooper, Jr .

11. D. J. Craig

12. J. H. DeVan

13. J. R. DiStefano

14. R. L. Heestand

15. J. A. Horak

16. 0. F. Kimbal1
17-21. M. J. Kania

22. E. L. Long, Jr.

23. R. W. McClung

24. R. E. Pawe 1

25-29. M. A. Schmidt

30. D. P. Stinton

31-33. P. T. Thornton

34. F. W. Wiffen

35. G. Y. Chin (Consultant)

36. H. E. Cook (Consultant)

37. F. F. Lange (Consultant)

38. T. E. Mitchell (Consultant)

39. W. D. Nix (Consultant)

40. J. C. Williams (Consultant)

EXTERNAL DISTRIBUTION

41. BATTELLE PACIFIC NORTHWEST LABORATORIES, P.0. Box 999 , Richland, WA 99352

J. 0. Barner

42-47. GENERAL ELECTRIC COMPANY, Space Nuclear Engineering and Technology Operations, P.0. Box 530954, San Jose, CA 95153-5354

H. S. Bailey

M. Kangalaski

P. J. Ring

E. D. Sayre

S. Vaidyanathan

J. C. Whipple

48. GENERAL ELECTRIC COMPANY, Advanced Reactor Systems Department, 175 Curtner Avenue, San Jose, CA 95125

P. Roy

49-52. GENERAL ELECTRIC COMPANY, Astro-Space Systems Division, P.0. Box 8555, Philadelphia, PA 19101

D. E11iott

A. Josloff

R. J. Katucki

R. E. Morgan 
53-54. IDAHO NATIONAL ENGINEERING LABORATORY, P.0. Box 1625, Idaho Falls, ID 83415

J. W. Henscheid

R. E. Rice

55-58. HANFORD ENGINEERING DEVELOPMENT LABORATORY, P.0. Box 1970, Richland, WA 99352
C. M. Cox
D. S. Dutt
J. J. Holmes
R. J. Puigh

59-62. JET PROPULSION LABORATORY, 4800 Oak Grove Drive, Pasadena, CA 91109
R. R. Ferber
J. F. Mondt
V. C. Trusce11o
R. H. Smoak

63-70. LOS ALAMOS NATIONAL LABORATORY, P.0. Box 1663, Los Alamos, NM 87545
R. E. Baars
R. Behrens
D. W. Carroll
J. E. Hanson
C. W. Hoth
R. B. Matthews
R. E. Mason
M. B. Parker

71-73. NASA LEWIS RESEARCH CENTER, 2100 Brookpark Road, Cleveland, OH 44135

H. S. Bloomfield

J. R. Stephens

R. H. Titran

74. NUS CORPORATION, 910 Clopper Road, Gaithersburg, MD 30878
A. Weitzberg

75-76. WESTINGHOUSE ELECTRIC CORPORATION, Advanced Energy Systems

Division, P.0. Box 10864, Pittsburgh, PA 15236
A. Boltax
R. W. Buckman

77-79. DOE, DIVISION OF DEFENSE ENERGY PROJECTS, NE-521 (GTN), Washington, DC 20545
W. P. Carrol1
J. A. Sholtis
E. J. Wahlquist 


\section{$13 \mid 1 \psi$}

80. DOE, OAK RIDGE OPERATIONS OFFICE, P.O. Box E, Oak Ridge, TN 37831 Office of Assistant Manager for Energy Research and Development

81-84. DOE, SAN FRANCISCO OPERATIONS OFFICE, 1333 Broadway, Oakland, CA 94612
W. E. Keheley
R. Saalborn
S. L. Samuelson
W. L. Von Flue

85-212. DOE, TECHNICAL INFORMATION CENTER, Office of Information Services, P.0. Box 62, Oak Ridge, TN 37831

For distribution as shown in DOE/TIC-4500, Distribution Category UC-25 (Materials) 
